\title{
Trade Finance in the Polish Corporate Sector: Balancing Growth and Financing Constraints
}

\author{
Pawel Mielcarz, Dmytro Osiichuk*
}

\begin{abstract}
The paper studies the determinants of trade credit in the Polish corporate sector. In addition to the readily understandable transaction motive, we investigate the influence of the company's liquidity, leverage and access to capital markets on its willingness to grant trade credit. Our findings suggest that firms actively adjust their trade receivables in order to avoid potential problems related to overtrading. We also find that more leveraged and more financially constrained companies are less likely to grant trade credit. Additionally, the paper studies the influence of the crisis settings on the dynamics of trade credit. We find that the outbreak of the crisis of 2008 caused companies to relax their trade credit policies which may speak in favour of the channelling theory of trade credit. The paper contributes to the on-going discussion on working capital management in the emerging economies.
\end{abstract}

Keywords: trade finance, receivables, overtrading, financing constraints

\section{Introduction}

International research (Seifert et al., 2013) suggests that trade receivables may reach as much as $40 \%$ of a company's sales with significant variations between countries and industries (Ng et al., 1999). The high share of accounts receivable in a firm's total assets causes companies to look for efficient ways of optimizing their trade credit policies in order to balance the sales stimulus with the costs of working capital finance.

The paper aims at studying the determinants of trade credit based on the data from the Polish corporate sector. In particular, the paper concentrates on the management of account receivables in relation to other elements of working capital. We also study how a company's access to capital markets, the overall financial health, and the general economic conjuncture that may shape trade credit policy.

The paper is structured as follows: first, we present the theoretical framework of the analysed problem; then we elaborate the research hypotheses and present the dataset; a presentation of the empirical research outcomes and a discussion of its practical implications conclude the paper.

\footnotetext{
* dr hab. Paweł Mielcarz, Akademia Leona Koźmińskiego w Warszawie, Katedra Finansów, e-mail: pmielcarz@ alk.edu.pl; mgr Dmytro Osiichuk, Akademia Leona Koźmińskiego w Warszawie, Katedra Finansów, e-mail: dosiichuk@alk.edu.pl.
} 


\section{Literature Review}

The classical models of trade credit (Schwartz, 1974) distinguish between two primary motives behind trade finance, i.e., transactions motive and financing motive. The former is an inherent element of business relations which stems from the need to provide customers with some leeway in payment terms in order to accommodate additional purchases in their cash flow planning and facilitate the transaction settlement. The reward for the seller resides in the increased revenues. The latter motive is the source of a long-lasting debate with the core questions revolving around the factors forcing non-financial businesses to recur to financial intermediation by effectively substituting trade finance for short-term external capital. The ultimate goal of financial management is to reconcile the beneficial revenue stimulating the role of the trade credit with the costs of implementation of a more aggressive working capital management strategy.

Yazdanfar and Ohman (2015) studied the influence of trade credit on the dynamics of sales of SMEs and concluded that companies implementing a more aggressive trade credit policy were more likely to boost their revenues. The positive effect of receivables finance appears to be particularly pronounced for trade relationships involving financially constrained counterparties. Hence, one of the primary goals of trade credit policy may consist in generating additional revenues by implicitly providing constrained clients with additional financial resources.

Ferris (1981) explains the recurrence to trade finance by an exchange costs minimization motive. The possibility to separate the exchange of goods from a monetary settlement supposedly constitutes the principal advantage of trade finance and underlies the transactions theory of trade credit. Summers and Wilson (2002) highlight the importance of accounts receivable as a vehicle facilitating the mismatches between inventory rotation and cash payments, thereby, allowing for a greater flexibility in setting the transaction terms.

Smith (1987) highlights the role of trade credit in alleviating the problem of information asymmetry. Granting trade credit may help the seller better identify credit and counterparty risks than in the case of intermediation by a financial institution. Such information may turn out to be particularly useful for coordinating corrective actions if the seller made nonsalvageable investments in its counterparties.

The equilibrium theoretical models (Ferris, 1981; Emery, 1984) suggest that companies having a better access to capital markets should have a better capacity to grant trade finance and thereby, increase their sales. However, the outcomes of empirical research cast doubt on this conclusion. Fabbri and Klapper (2008) concluded that sellers with lower market power were more likely to relax trade credit terms and sell a larger share of their output on credit. The same study suggests the lack of influence of financing constraints or a firm's profitability on the trade credit terms and points to the pervasive practice of matching the receivables and payables days. Brennan et al. (1988) argue that recurrence to trade credit 
allows sellers to practice price discrimination among counterparties with different price elasticity's of demand.

Studying the financing motive standing behind trade finance Petersen and Rajan (1996) found that financially constrained companies may be more prone to recurring to financing their purchases with trade credit. Hence, medium term trade credit appears to substitute for bank credit. Suppliers may be better informed about the financial condition of their counterparties and have an implicit stake in their long-term operations. Therefore, suppliers may be effectively channelling credit resources to their constrained counterparties and thus alleviate the problem of limited access to capital markets. Danielson and Scott (2004) report a positive influence of financing constraints on the demand for trade finance. Other studies (Chant, Walker, 1988) suggest that trade finance may be both a substitute and a complement to bank credit. Yet another study (Carvalho, Schiozer, 2015) reports that trade credit is complementary to bank credit. Therefore, trade credit may be used by financial institutions as an indicator of the company's creditworthiness.

Ferrando and Mulier (2013) analyse how companies use accounts payable and accounts receivable to manage their growth. The authors argue that a combination of both components of working capital is used to channel credit resources and alleviate the imperfections of capital and product markets. On the one hand, firms ask for trade credit in order to minimize transaction costs, manage their cash flows properly and finance their production processes. On the other hand, they grant trade credit in order to increase sales to their customers, which may have a limited access to capital markets. Ferrando and Mulier (2013) evidence that financially constrained companies are more reliant on trade credit channel to finance their growth and compensate for their limited access to external finance. Additionally, the same study shows that the outbreak of the financial crisis in 2008 increased the importance of the credit trade channel and forced companies to increasingly recur to trade finance in order to accommodate the consequences of the credit crunch.

Bastos and Pindado (2013) describe a phenomenon of a credit contagion whereby an economic crisis causes an increased reliance on the credit trade channel in the corporate sector with the effect being particularly pronounced for the financially constrained companies. The findings speak in favour of the substitution hypothesis. The companies with increased liquidity risks due to a relatively greater share of sales on credit are found to be more likely to alleviate insolvency risks by delaying payments to their suppliers. The latter effect appears to be magnified under conditions of an economic downturn.

To sum up, the existing literature offers a multifaceted and often ambiguous picture of the factors shaping trade credit policy. What is more, the problem appears to be largely covering mature post-industrial economies with well-developed capital markets. Research on data from the Polish corporate sector appears to be particularly scarce. Most existing papers cover the problem of working capital management rather from the practitioner's standpoint (Cegłowski, Wnuczak, 2010; Wnuczak, 2014). This paper attempts to fill in the gap and contribute to the discussion over the significance of trade credit in the emerging economies. 


\section{Hypotheses Development}

The paper represents an attempt to define the key determinants of the trade credit policy in the Polish corporate sector. For the purposes of this paper the explained variable is only the dynamic of accounts receivable. The accounts payable are analysed as an explanatory variable, which is dictated by the research design. Table 1 summarizes the research hypotheses which mostly derive from the existing literature.

The paper attempts to provide clarification for some of the ambiguities existing in the literature. We analyse both the transaction and financing motive underlying trade credit decisions. Apart from willingness to provide some leeway to the customer in terms of transactions settlement, trade receivables may also be used as an efficient tool of a company's liquidity management. For example, the logic of financial decision making suggests that a company might be willing to increase sales on credit, if during the prior reporting period it accumulated excessive inventories. The receivables dynamics may also be highly correlated with the changes in payables balance as suggested by the matching hypothesis. Higher sales might not necessarily be accompanied with an increase of receivables as implied in the existing literature, because disproportionate credit sales growth might ultimately cause serious liquidity problems and other symptoms characteristic for overtrading.

\section{Table 1}

Hypotheses Summary (Explained Variable: Change in Accounts Receivable YoY Scaled by Total Assets)

\begin{tabular}{|c|c|c|c|c|}
\hline Hypothesis & Variable & Proxy & Sign & Underlying theory \\
\hline 1 & 2 & 3 & 4 & 5 \\
\hline \multirow[t]{4}{*}{$\begin{array}{l}\text { H1. Larger companies are } \\
\text { likely to grant more trade } \\
\text { credit ceteris paribus }\end{array}$} & \multirow[t]{4}{*}{ Size } & \multirow{4}{*}{$\begin{array}{l}\text { Natural } \\
\text { logarithm } \\
\text { of a com- } \\
\text { pany's total } \\
\text { assets }\end{array}$} & + & $\begin{array}{l}\text { Better access to capital markets enables larger companies } \\
\text { to sell more on credit thereby increasing their market share } \\
\text { (Schwartz, 1974) }\end{array}$ \\
\hline & & & & $\begin{array}{l}\text { Larger companies are better positioned to collect the ne- } \\
\text { cessary information regarding the creditworthiness of their } \\
\text { counterparties and have a greater stake in their long-term } \\
\text { operations (Smith, 1987) }\end{array}$ \\
\hline & & & & $\begin{array}{l}\text { Larger companies are better positioned to practice price } \\
\text { discrimination (Brennan et al., 1988) }\end{array}$ \\
\hline & & & - & $\begin{array}{l}\text { Small financially constrained companies with weaker market } \\
\text { power are more likely to rely on the trade credit channel to } \\
\text { finance their growth (Fabbri, Klapper, 2008) }\end{array}$ \\
\hline $\begin{array}{l}\text { H2. Companies with better } \\
\text { growth opportunities are } \\
\text { likely to grant more trade } \\
\text { credit }\end{array}$ & $\begin{array}{l}\text { Growth op- } \\
\text { portunities }\end{array}$ & $\mathrm{P} / \mathrm{BV}$ ratio & + & $\begin{array}{l}\text { Constrained growth companies are more likely to rely on the } \\
\text { trade credit channel (Yazdanfar, Ohman, 2015) }\end{array}$ \\
\hline $\begin{array}{l}\text { H3. Companies which have } \\
\text { accumulated relatively } \\
\text { more inventory in the } \\
\text { previous reporting period } \\
\text { are likely to grant more } \\
\text { trade credit }\end{array}$ & $\begin{array}{l}\text { Inventory } \\
\text { change }\end{array}$ & $\begin{array}{l}\text { Change in } \\
\text { Invento- } \\
\text { ry YoY } \\
\text { Scaled } \\
\text { by Total } \\
\text { Assets }\end{array}$ & + & $\begin{array}{l}\text { Trade credit allows to reduce the average inventory invest- } \\
\text { ment thanks to the accurate planning of goods dispatching } \\
\text { (Schwartz, 1974) }\end{array}$ \\
\hline
\end{tabular}




\begin{tabular}{|c|c|c|c|c|}
\hline 1 & 2 & 3 & 4 & 5 \\
\hline \multirow[t]{2}{*}{$\begin{array}{l}\text { H4. More indebted compa- } \\
\text { nies are likely to grant less } \\
\text { trade credit }\end{array}$} & \multirow[t]{2}{*}{ Leverage } & \multirow[t]{2}{*}{$\begin{array}{l}\text { Leverage } \\
\text { ratio }\end{array}$} & + & $\begin{array}{l}\text { Trade credit is complementary to bank credit (Carvalho, } \\
\text { Schiozer, 2015). Argument in favour of the trade credit } \\
\text { channelling theory. }\end{array}$ \\
\hline & & & - & $\begin{array}{l}\text { Trade credit is a substitute for bank credit (Danielson, Scott, } \\
\text { 2004). The trade credit policy is shaped by the cost effect of } \\
\text { accounts receivable. Solvency is the priority. }\end{array}$ \\
\hline $\begin{array}{l}\text { H5. Companies are likely } \\
\text { to match the timing and } \\
\text { values of their receivables } \\
\text { and payables }\end{array}$ & $\begin{array}{l}\text { Payables } \\
\text { change }\end{array}$ & $\begin{array}{l}\text { Payables } \\
\text { Change } \\
\text { YoY } \\
\text { Scaled } \\
\text { by Total } \\
\text { Assets }\end{array}$ & + & $\begin{array}{l}\text { Increase in receivables should be accompanied with a respec- } \\
\text { tive increase in payables and vice versa (Bastos, Pindado, } \\
\text { 2013) }\end{array}$ \\
\hline \multirow{2}{*}{$\begin{array}{l}\text { H6. Intensive sales growth } \\
\text { is likely to be accompanied } \\
\text { with a receivables increase }\end{array}$} & \multirow[t]{2}{*}{$\begin{array}{l}\text { Sales } \\
\text { growth }\end{array}$} & \multirow{2}{*}{$\begin{array}{l}\text { Sales } \\
\text { growth } \\
\text { YoY }\end{array}$} & + & $\begin{array}{l}\text { Companies use receivables as a tool to enhance revenue } \\
\text { growth (Yazdanfar, Ohman, 2015) }\end{array}$ \\
\hline & & & - & $\begin{array}{l}\text { Companies are primarily trying to avoid problems related to } \\
\text { overtrading }\end{array}$ \\
\hline \multirow{2}{*}{$\begin{array}{l}\text { H7. More profitable and } \\
\text { more liquid companies } \\
\text { are more likely to pursue } \\
\text { an aggressive trade credit } \\
\text { policy }\end{array}$} & \multirow{2}{*}{$\begin{array}{l}\text { Profitabi- } \\
\text { lity, cash } \\
\text { position }\end{array}$} & \multirow{2}{*}{$\begin{array}{l}\text { ROA, Cash } \\
\text { and Cash } \\
\text { Equ- } \\
\text { ivalents } \\
\text { Scaled } \\
\text { by Total } \\
\text { Assets }\end{array}$} & + & $\begin{array}{l}\text { Profitable companies rich in cash are better positioned to } \\
\text { channel credit resources to their constrained counterparties }\end{array}$ \\
\hline & & & - & $\begin{array}{l}\text { Financially constrained status implying high cash reserves } \\
\text { precludes companies from granting additional trade credit } \\
\text { (Kling et al., 2014) }\end{array}$ \\
\hline \multirow{2}{*}{$\begin{array}{l}\text { H8. Financially constrained } \\
\text { companies are likely to } \\
\text { pursue a more conservative } \\
\text { trade credit policy }\end{array}$} & \multirow[t]{2}{*}{$\begin{array}{l}\text { Financing } \\
\text { constraints }\end{array}$} & \multirow{2}{*}{$\begin{array}{l}\text { Binary } \\
\text { variable } \\
\text { WSE, bina- } \\
\text { ry variable } \\
\text { Constraints }\end{array}$} & - & $\begin{array}{l}\text { Financially constrained companies are not able to grant exces- } \\
\text { sive amounts of trade credit due to limited financial resources }\end{array}$ \\
\hline & & & + & $\begin{array}{l}\text { Financially constrained companies are more reliant on the } \\
\text { trade credit channel (Fabbri, Klapper, 2008) }\end{array}$ \\
\hline \multirow{2}{*}{$\begin{array}{l}\text { H9. A financial crisis forces } \\
\text { companies to increase their } \\
\text { reliance on trade credit }\end{array}$} & \multirow[t]{2}{*}{ Crisis } & \multirow{2}{*}{$\begin{array}{l}\text { Binary } \\
\text { variable } \\
\text { Crisis }\end{array}$} & + & $\begin{array}{l}\text { A crisis forces the corporate sector to rely more on trade credit } \\
\text { (Bastos \& Pindado, 2013) }\end{array}$ \\
\hline & & & - & $\begin{array}{l}\text { A crisis forces companies to chase their receivables in order to } \\
\text { fill in the liquidity gaps }\end{array}$ \\
\hline
\end{tabular}

Source: own elaboration.

\section{Dataset and Methodology}

The dataset is comprised of 905 Polish companies quoted on the main market of the Warsaw Stock Exchange and on New Connect. The observation period is from 1997 to 2014. The data was retrieved from the Notoria database. The resulting unbalanced panel dataset excludes financial companies but contains companies which ceased to exist in order to avoid the survivorship bias. The dataset was winsorized at the $1 \%$ level.

In order to verify the enumerated hypotheses we constructed the following general econometric model:

$$
\begin{gathered}
\left(\frac{\left.\Delta \text { Receivables YoY }_{\text {Total Assets }}\right)=}{=f\left(\log \text { Assets; } \frac{P}{B V} ;\left(\frac{\Delta \text { Inventory YoY }_{-1}}{\text { Total Assets }_{-1}}\right) ; \text { Leverage }_{-1} ;\left(\frac{\Delta \text { Payables YoY }_{-1}}{\text { Total Assets }_{-1}}\right) ; \Delta \text { Sales; ROA; Cash }_{-1} ; \text { Constraints }\right)}\right.
\end{gathered}
$$


where:

$\left(\frac{\Delta \text { Receivables YoY }}{\text { Total Assets }}\right)$ - explained variable, change in receivables YoY scaled by con-temporaneous total assets,

logAssets - natural logarithm of the company's total assets,

$P / B V \quad-$ company's price-to-book ratio,

$\left(\frac{\Delta{\text { Inventory } \text { YoY }_{-1}}_{\text {Total Assets }}}{\text { An }_{1}}\right)-\begin{aligned} & \text { change in inventory YoY scaled by total assets lagged by one } \\ & \text { period, }\end{aligned}$ Leverage $_{-1} \quad-$ company's leverage ratio lagged by one period,

$\left(\frac{\Delta{\text { Payables } \text { YoY }_{-1}}_{\text {Total Assets }}}{\text { Toti }}\right)$ - change in payables scaled by total assets lagged by one period, $\triangle$ Sales $\quad-$ increase in firm's revenues,

ROA - return on assets,

Cash $_{-1} \quad-$ cash and cash equivalents scaled by total assets lagged by one period,

Constraints - different proxies for financing constraints.

We defined three proxies for financing constraints. WSE - binary variable, where 1 encodes companies quoted on the main market of the Warsaw Stock Exchange (these companies are assumed to be financially unconstrained) and 0 encodes all other companies in the research sample. We assume that companies quoted on the main market are less likely to suffer from information asymmetry problems and are more likely to have better access to capital markets.

Constraints - a binary variable, where 1 encodes financially constrained companies and 0 encodes financially unconstrained companies. The variable was constructed using the methodology originally proposed by Devereux and Schiantarelli (1990). We replaced a company's age with the time elapsed since the company's IPO (Time). Based on the Time $\times$ Size indicator (where Size is approximated by the natural algorithm of the company's assets) we divided the sample into two equal parts: firms with the Time $\times$ Size indicator above the median for the sample were denoted as unconstrained (0), their counterparts with the Time $\times$ Size indicator below the median were labelled as financially constrained (1).

Crisis - we introduced a binary variable equal to 1 for observations in the years 2008 2011 and zero otherwise. This variable is expected to show the influence of the economic downturn on the dynamics of the explained variable. Crises usual cause exacerbation of the problem of financing constraints, especially if they render access to capital markets more difficult as it was in the case of the crisis of 2008-2011. 


\section{Empirical Results}

We ran static panel regression models with random effects, year and industry dummies. Table 2 presents the results of the empirical tests of the formulated research hypotheses. The tested models possess satisfactory econometric properties allowing for valid inferences. AR(1) and AR(2) tests confirm that there is no serial correlation of the disturbances. Several independent variables are jointly and separately statistically significant. The respective signs and values of the coefficients persist despite changes in the model specification.

The negative statistically significant coefficient at Ln Assets allows rejecting $\mathrm{H} 1$. The empirical results corroborate the results of the prior studies: smaller companies are found to be relatively more reliant on the trade credit channel to manage their growth potential. Smaller (and as a consequence more likely to be financially constrained) companies appear to sell relatively more on credit and grant more trade credit to their customers. Prior studies suggest that such a strategy may aim at securing a competitive advantage and thus attracting new clients or simply at matching accounts payable.

The coefficient at the price-to-book ratio is not statistically significant suggesting the lack of a connection between growth opportunities and trade credit policy.

The coefficient at Inventory change is statistically significant at the conventional $1 \%$ level. We fail to reject H3. Hence, it may be inferred that Polish companies use sales on credit to sell the excessive inventories accumulated in the previous reporting period. This finding highlights the importance of active working capital management for maintaining a firm's liquidity and profitability.

The negative coefficient at Leverage lagged by one period suggests that highly leveraged companies may be reluctant to grant trade credit possibly in order to maintain solvency and be able to meet short-term liabilities without incurring significant counterparty and credit risks.

Insignificant coefficients at payables change, scaled by total assets and lagged by one reporting period cast doubt on the validity of the matching hypothesis. Trade receivables appear to have no connection with the dynamics of trade payables. It may suggest that the two variables are shaped by different sets of determinants. These findings undermine the postulates of the credit channel theory and may prompt a further discussion on the key factors influencing working capital management decisions.

A negative and statistically significant coefficient at Sales Growth YoY speaks for a rejection of H6. Intensive sales growth appears to be accompanied only with a moderate increase of trade receivables. This may point to the fact that firms are trying to avoid the hardships of overtrading and maintain liquidity instead of fuelling sales growth with even more sales on credit.

The negative sign of the coefficients at Cash and Cash Equivalents scaled by Total Assets lagged by one period allows rejecting H7. Our findings are in accord with the existing literature which suggests that financially constrained companies may be less likely to grant trade credit but generally maintain higher cash balances. Hence, the causation is implicit here. 


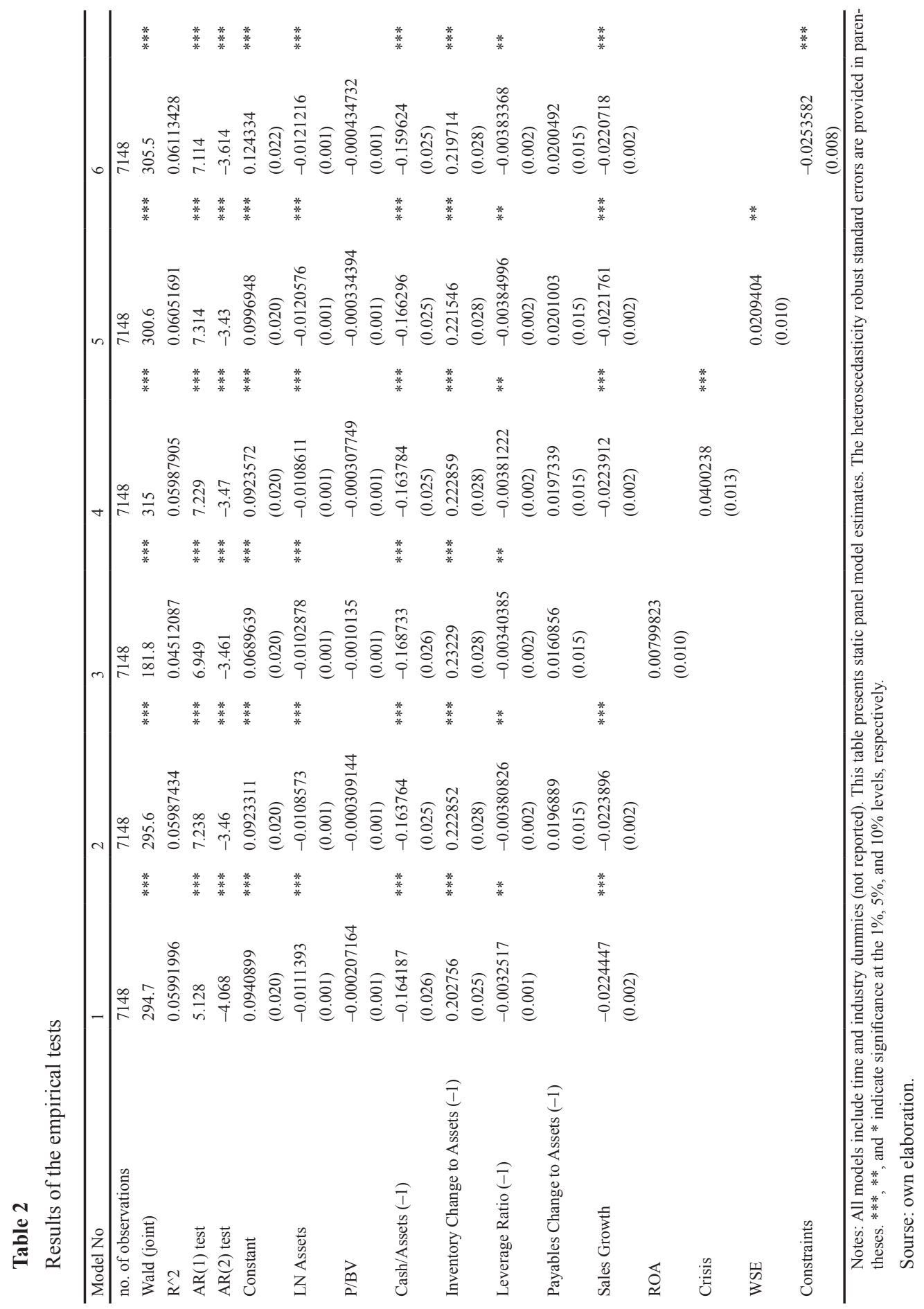


The statistical insignificance of the coefficient at ROA suggests lack of interrelation between a company's profitability and its trade credit policy, thereby speaking in favour of the rejection of $\mathrm{H} 7$.

The proxies for financing constraints give an unambiguous indication in favour of $\mathrm{H} 8$. Financially constrained companies appear to be likely to grant less trade credit ceteris paribus. Firms quoted on the main market of the WSE (deemed to be financially unconstrained) are found to pursue a more aggressive trade credit policy.

The regressor Crisis is statistically significant at the $1 \%$ level. We failed to reject $\mathrm{H} 9$. Our findings are consistent with the existing literature, which postulates an increased reliance on trade credit during an economic downturn. These results partially corroborate the postulates of the credit contagion theory (Bastos, Pindado, 2013), however, we found no significant relationship between the dynamics of accounts payable and accounts receivable, so further research may be necessary on the mechanism of the influence of the external supply-side cash flow shocks on trade credit policy.

\section{Concluding Remarks}

The paper has presented a systematized overview and empirical tests of the key determinants of trade credit policy in the Polish corporate sector. Overall, we found that when making trade credit decisions, firms appear to be primarily concerned with preserving liquidity, selling off redundant inventories, avoiding overtrading, and maintaining solvency by setting a cap to the costs of working capital finance. We have not found any evidence in favour of the matching theory. Financially constrained companies appear to grant relatively less trade credit. Economic crises, which are likely to aggravate financing constraints, appear to limit a company's willingness to grant trade credit.

Our empirical findings strongly suggest that the Polish corporate sector is facing financing constraints. Further normative research may be necessary to address the existing issues to make it possible to come up with corrective actions aimed at ameliorating access to capital markets. Additionally, we highlighted the crucial role of working capital management in channelling a firm's growth.

\section{References}

Bastos, R., Pindado, J. (2013). Trade credit during a financial crisis: A panel data analysis. Journal of Business Research, 66 (5), 614-620.

Brennan, M., Maksimowic, V., Zechner, J. (1988). Vendor financing. Journal of Finance, 43 (5), 1127-1141.

Carvalho, C., Schiozer, R. (2015). Determinants of Supply and Demand for Trade Credit by Micro, Small and Medium-Sized Enterprises. Revista Contabilidade \& Finanças, 26 (68). DOI: 10.1590/1808-057x201500940.

Cegłowski, B., Wnuczak, P. (2010). Advanced techniques of planning of accounts receivable and accounts payable. Zeszyty Naukowe Uniwersytetu Szczecińskiego, 587, Finanse, Rynki Finansowe, Ubezpieczenia, 323-336.

Chant, E., Walker, D. (1988). Small business demand for trade credit. Applied Economics, 20, 861-876.

Danielson, M., Scott, G. (2004). Bank loan availability and trade credit demand. The Financial Review, 39, 579-600. 
Devereux, M., Schiantarelli, F. (1990). Investment, financial factors, and cash flow: Evidence from UK panel data. In: R. Hubbard (ed.), Asymmetric Information, Corporate Finance and Investment (pp. 279-306). Chicago: University of Chicago Press.

Emery, G. (1984). A pure financial explanation for trade credit. The Journal of Financial and Quantitative Analysis, 19 (3), 271-285

Fabbri, D., Klapper, L. (2008). Market Power and the Matching of Trade Credit Terms. The World Bank.

Ferrando, A., Mulier, K. (2013). Do firms use the trade credit channel to manage growth? Journal of Banking \& Finance, 37 (8), 3035-3046.

Kling, G., Paul, S., Gonis, E. (2014). Cash holding, trade credit and access to short-term bank finance. International Review of Financial Analysis, 32, 123-131.

$\mathrm{Ng}$, C., Smith, J., Smith, R. (1999). Evidence on the determinants of credit terms used in interfirm trade. The Journal of Finance, 54 (3), 1109-1129.

Petersen, M., Rajan, R. (1997). Trade credit: theories and evidence. The Review of Financial Studies, 10 (3), 661691.

Schwartz, R. (1974). An Economic Model of Trade Credit. Journal of Financial and Quantitative Analysis, 9 (4), 643-657.

Seifert, D., Seifert, R., Protopappa-Sieke, M. (2013). A review of trade credit literature: Opportunities for research in operations. European Journal of Operational Research, 231, 245-256.

Smith, J. (1987). Trade credit and informational asymmetry. The Journal of Finance, 42 (4), 863-872.

Summers, B., Wilson, M. (2002). An empirical investigation of trade credit demand. International Journal of the Economics of Business, 9 (2), 257-270.

Wnuczak, P. (2014). Modified liquidity ratio as an alternative to traditional financial liquidity indicators. Optimum. Studia Ekonomiczne, 4 (70), 192-211.

Yazdanfar, D., Ohman, P. (2015). The impact of credit supply on sales growth: Swedish evidence. International Journal of Managerial Finance, 11 (3), 329-340.

\section{KREDYT KUPIECKI W POLSKICH PRZEDSIĘBIORSTWACH: WZROST I OGRANICZENIA KAPITALOWE}

Streszczenie: W artykule przedstawiono wyniki badań w zakresie determinant kształtujących poziom kredytów kupieckich udzielanych przez polskie przedsiębiorstwa. Oprócz oczywistych motywów transakcyjnych, badanie objęło analizę wpływu na poziom kredytów kupieckich takich czynników jak poziom płynności, zadłużenia oraz dostęp do rynku kapitałowego. Uzyskane wyniki wskazują, że spółki aktywnie dostosowują poziom udzielanych kredytów kupieckich w celu uniknięcia problemów wynikających z nadmiernego kredytowania odbiorców. Ponadto badania wykazały, że firmy mocniej zadłużone i w większym stopniu ograniczone kapitałowo charakteryzują się mniejszą dynamika kredytów kupieckich od pozostałych podmiotów. W artykule przedstawiono także wyniki badań w zakresie wpływu kryzysu na dynamikę należności, z których wynika, że początek kryzysu datowany na rok 2008 wpłynął na poluzowanie polityk kredytowych polskich przedsiębiorstw, co przemawia za teorią ukierunkowania w zakresie udzielania kredytów kupieckich. Przedstawione wyniki stanowią wkład do toczącej się dyskusji na temat zarządzania kapitałem obrotowym na rynkach wschodzących.

Słowa kluczowe: kredyt kupiecki, należności, overtrading, ograniczenia kapitałowe

\section{Citation}

Mielcarz, P., Osiichuk, D. (2017). Trade Finance in the Polish Corporate Sector: Balancing Growth and Financing Constraints. Finanse, Rynki Finansowe, Ubezpieczenia, 1 (85), 119-128. DOI: 10.18276/frfu.2017.1.85-10. 